the analysis of an author's entire works can shed light on an intellectually "intense" figure. Non-specialists will have the opportunity to discover an author who, though in many ways still not well known, was in fact a much admired intellectual of his time.

ELENA BRIZIO

Georgetown University (Fiesole Campus)

\title{
Rico, Francisco.
}

I venerdi del Petrarca. Seguito da "Profilo biografico del Petrarca" in collaborazione con Luca Marcozzi.

Piccola Biblioteca Adelphi 693. Milan: Adelphi, 2016. Pp. 219. ISBN 978-88459-3103-1 (paperback) €14.

"Of all who lived during or before his time, none offers a life as fully documented as Petrarch's. Yet such details mostly derive from his direct testimony, and include conflicting and always more or less re-elaborated elements that, by veiling or manipulating historical data, aim at building an ideal autobiography." (69) With this statement, which echoes a previous one by Ernest H. Wilkins, Catalan philologist Francisco Rico inaugurates his account of Petrarch's life (written in collaboration with Luca Marcozzi). It constitutes the second part of a very enjoyable work whose first part, Petrarch's Fridays, carries the book's main title.

Francesco Petrarca (or simply Petrarch according to the English version of his name) was born in Arezzo in 1304 to a Florentine notary who was at that time exiled from his native land for the same reason as Dante. Even Petrarch's name and dates are subject to elaboration and to discrepancy between his writings, documents, and biographers-which proves how slippery is the ground for modern specialists.

Taking inspiration from how Petrarch moulded his own biography, Rico noticed that in many instances of Petrarchan oeuvre, one weekday always peeps out: Friday. As a typically penitential day, a day of fasting and meditation in the Catholic tradition, Friday for Petrarch used to represent the temporal background for fundamental facts, either positive or negative. For that reason, 
whenever this particular day occurs in his writings or marginal notes, it must be interpreted as a sign of importance.

In his essay, Rico examines the recurrence of Friday in Petrarch's works. Giovanni, Petrarch's son, died on Friday; three of Petrarch's renowned epistles addressed to antique authors (Cicero, Seneca, and Homer) were originally signed on a Friday; and most of the Petrarchan-dated corrections of his vernacular poems (Rerum vulgarium fragmenta) occurred on Friday. More significantly, all the main turning points for Petrarch's life and career took place, in his reconstruction, on a Friday: the ascent of Mont Ventoux in Provence under the full moon (Friday 26 April 1336); and his arrival and poetical coronation in Rome (in April 1341 before and after Easter, respectively).

The other pivotal episode in Petrarch's Rerum vulgarium fragmenta-that is, the first appearance of his beloved Laura-was originally set on Friday. As Rico recollects, in the original version of one sonnet that preserves an allusion to it (RVF 211), the poet claims to have met Laura on "the sixth day of April," to wit a Friday (according to the Christian calendar, the week starts on Sunday), and not April the 6th. Only later in his life, Petrarch added the year (1327), and in doing so he attributed to "the sixth day of April" the seal of a real complete date: 6 April 1327. This brought readers to merge the two pieces of evidence and to add the further element of the liturgical celebration of Good Friday, something that Petrarch never states. For a true Christian, as he was, any Friday was a Good Friday.

The latter example illustrates the itinerary of Petrarch's interpretation of his life as reflected in his works: not a historical account with precise dates, names, and facts, but an exemplary story corresponding to the common human experience of any time. Here, and in his own literary style, Petrarch adopts a vague, if not ambiguous, approach in order to assimilate the incongruities coming from different versions of the same work within a global picture. Moreover, through his continuous attention to time, Petrarch shows a sort of apotropaic approach: "to mention time is in a manner to dominate it" (37).

The second part of the book dwells on the wealth of political details that influenced Petrarch's choices of residence, patrons, and official missions in France, Italy, and the empire. Rico reinstates political stances that the author wanted to hide in his public writings (especially in his epistolary collections). Petrarch's engagement, although veiled in many of his Familiares, clearly emerges from his parallel Liber sine nomine (Book without a title, but also 
"without names" of the addressees), where Petrarch gathers his most politically compromising letters, and in general from the role of confidential counsellor of the mighty - a role he strove for in the 1350s.

From a literary point of view, the biographical profile illustrates with few (but firm) touches all works by Petrarch and their relative manuscript traditions and modern editions. In particular, Rico examines how Petrarch evolved from considering himself a poet and a historian at the age of the poetical coronation, in 1341, to claiming the title of philosopher after his transfer to Milan in 1353 (145). To resort to a botanical image that also mirrors an actual change in his practice as amateur gardener, Petrarch abandoned the leaves of the laurel, the tree of poetry, to embrace those of the olive tree, the plant of wisdom.

Counting on a profound knowledge of classical texts, Christian thought, and current questions, Petrarch constructs a synthesis that permeates all the writings that he shaped, or re-shaped, in his "maturity": the Familiares and Seniles epistles, the Secretum, the invectives, and De remediis utriusque fortune. Petrarch founded, or contributed to found, the myth of Rome; he gave decisive support (later put into perspective) to Cola di Rienzo and his dream to organize a new government in the eternal city.

Based on an updated interpretation and reading of old and newly discovered data, Rico's account of Petrarch's figure and masterpiece is as close as possible to reality and not to the legend. As the critic repeatedly claims, it is impossible to turn all of the information disseminated in Petrarch's works into a consistent picture. Rico's attempt, however, deserves our high regard.

JOHNNY L. BERTOLIO

University of Toronto

\section{Rollo-Koster, Joëlle.}

Avignon and Its Papacy, 1309-1417: Popes, Institutions, and Society.

Lanham, MD: Rowman \& Littlefield, 2015. Pp. xiii, $314+2$ maps. ISBN 978-14422-1532-0 (hardcover) US\$75.

The Avignon papacy was not judged kindly by contemporaries. While chroniclers reviled the popes' subservience to the French crown, poets and penitents vilified the papal court for its immorality and corruption. In a 